\title{
Sibelius at the Crossroads: \\ Old Paths Leading to New Creative Departures in His Second Symphony (1901/02)
}

\author{
Nors S. Josephson
}

Sibelius' Second Symphony is a central milestone in his entire compositional output. Many commentators (including Haas ${ }^{1}$ and Murtomäki ${ }^{2}$ ) have stressed Sibelius' great indebtedness to Beethoven and Brahms, notably his use of axial major thirds that often lead to whole-tone scalar configurations. The latter derivations are familiar from classical development sections and later Russian composers such as Borodin and Musorgskij.

Sibelius' emphasis on tonal unity is already present in his earliest drafts for the Second Symphony, which highlight the keys of C and (its dominant) G:

1 David Haas, „Sibelius's Second Symphony and the Legacy of Symphonic Lyricism,“ in The Sibelius Campanion, ed. Glenda D. Goss (Westport: Greenwood, 1996), 81-82.

2 Veijo Murtomäki, Symphonic Unity: The Development of Formal Thinking in the Symphonies of Sibelius (Helsinki: Universitatis Helsingiensis, 1993), 48-52. Similar sentiments are expressed by James Burnett in The Music of Jean Sibelius (London: Associated University Presses, 1983), 58-59 and Marc Vignal in his Jean Sibelius (Paris: Fayard, 2004), 321. 
Table I: Initial emphasis on keys of C- and G-major in Sibelius' Second Symphony

\begin{tabular}{llll}
$\begin{array}{l}\text { Measures of } \\
\text { final version }\end{array}$ & Sketch draft in Helsinki University Library $(\mathrm{HUL})^{3}$ & $\begin{array}{l}\text { Year ac- } \\
\text { cording to }\end{array}$ & $\begin{array}{c}\text { Key } \\
\text { of sketch }\end{array}$ \\
& $\begin{array}{l}\text { Kilpeläinen's }_{\text {catalogue }^{3}} \\
\end{array}$ & \\
\hline
\end{tabular}

\begin{tabular}{lllc}
\hline $\begin{array}{l}\text { I Allegretto } \\
9-14 \text { in D, } \\
\text { Oboe }\end{array}$ & $\begin{array}{l}\text { 0818 [1]/3, line 11 (part of projected Kinderstücke, } \\
\text { possibly quoting the German folk song } \\
\text { Es klappert die Mühle am rauschenden Bach) }\end{array}$ & C \\
& $\begin{array}{l}\text { C } \\
9-14\end{array}$ & $1899-1898-1900$ & $\mathrm{~F}(!)$ \\
$9-14$ & $1514 / 2$, line 1 & $1899-1901$ & $\mathrm{C}$ \\
$9-14$ & $0146[2]$, line 5 & & $\mathrm{C}$ \\
$9-14$ & $1549 / 2$, line 11 & 1901 & $\mathrm{C}$
\end{tabular}

This last-listed source is evidently a later and more fully developed draft:

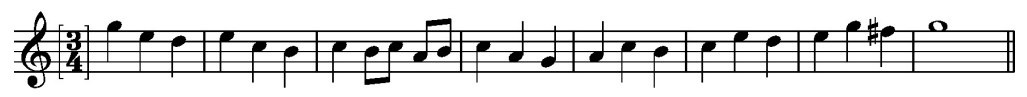

II Tempo Andante, ma rubato - Andante sostenuto

\begin{tabular}{|c|c|c|}
\hline $\begin{array}{l}40-55 \\
\text { in } \mathrm{d} \text {, Bassoons }\end{array}$ & $\begin{array}{l}\text { Rapallo sketch in } 0145 \text {, line } 3-6 \text {, subtitled Balletto } \\
\text { in minore. Serenata dell' estero, with subsequent } \\
\text { references to Don Juan and death in } 0145 / 2\end{array}$ & $\begin{array}{l}1901 \\
\text { (Feb. 11) }\end{array}$ \\
\hline $8-101$ & Christus sketch $1537 / 2$, in $3 / 4$ meter & $1900-1901$ \\
\hline
\end{tabular}

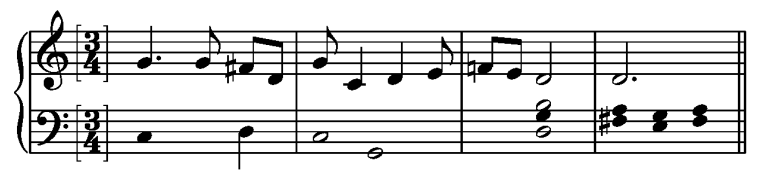

III Scherzo: Vivacissimo - Trio: Lento e soave

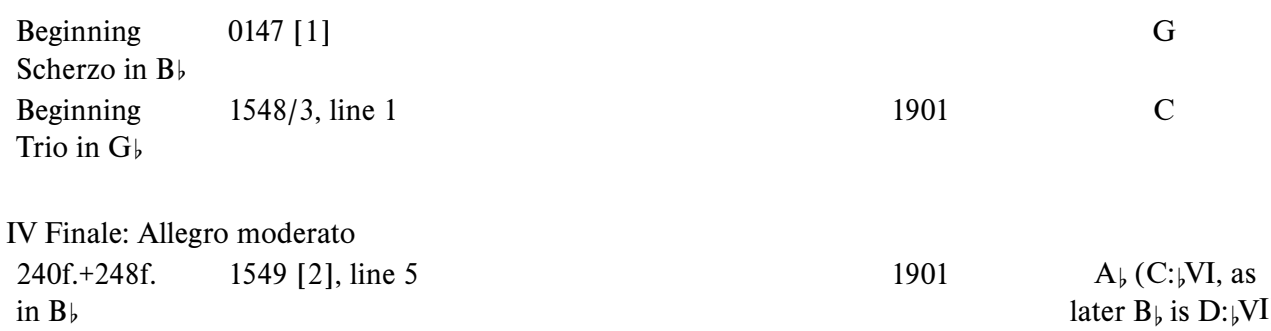

3 Kari Kilpeläinen, The Jean Sibelius Musical Manuscripts at Helsinki University Library: A Complete Catalogue (Wiesbaden: Breitkopf \& Härtel, 1991). 
As already mentioned, Sibelius' later drafts for his Second Symphony more consistently stress the axial major third relationships of $\mathrm{D}-\mathrm{F} \# / \mathrm{G}_{b}-\mathrm{B}_{b}-\mathrm{D}$, a procedure that is reminiscent of Beethoven's Seventh Symphony (1812; keys of A/a-C/c\#-F) and Brahms' Second Symphony (1877; keys of D-B $b-\mathrm{F} \#)$. Similar major third hierarchies are later encountered in the music of Béla Bartók, a composer admired by Sibelius, for instance in the Concerto for Orchestra (1943; C\#-F-A) and the Viola Concerto (1945; A-F-C/C\#). Let us summarize these major third hierarchies in Table II:

Table II: Axial major thirds in Sibelius' later drafts for his Second Symphony

D-major tonic area

$1,1-48$

I, 233-288

$1,318-333$

II, $1-91 \mathrm{~d}$

II, 179-207 d, C'hristus

II, 208-216 D

II, 221-239 d

\section{$\mathrm{F} \sharp / \mathrm{G}$ b episodes}

I, 224-228 Gb, end of development

1, 216-219 (end of development)

I, 293-300 F\#

II, 98-112 C'hristus, $\mathrm{F} \#$

II, $112-132 \mathrm{f} \#$

III, 146-158 Gb Trio

III, $1-27$

III, $82-142$

III, 161-226

III, 245-293

III, 293-297 Gb Trio

IV, 17-20 f\#

IV, 25-65 D

IV, 79-100 f \#

IV, 101-130 F\#

IV, 197-212 D

IV, 213-216 f\#

IV, 221-239 D

IV, 240-262

IV, 273-334 d

IV, 335-373 D

It will be noted that the initial F\#-major/f\#-minor spheres (or D:III/iii) in movements II and IV are often associated with static, ostinato-like formal structures, whereas the B areas in I, III and IV are typically more developmental in nature. $\mathrm{B} b$ also tends to resolve downwardly to A via its enharmonic equivalent, A\#, as seen in F\#-major (with A\#) progressing to F\#-minor (with upper $A_{\natural}$ ) between movements I, II and IV. 
In addition, Sibelius is careful - as noted earlier - to link these three tertial spheres with major second/whole-tone transitions in the style of Classical period development sections. (Compare, for instance, Mozart's Jupiter Symphony: I and Beethoven's First Symphony: I, with their profiled whole-tone progressions around $\mathrm{E} b-\mathrm{f}-\mathrm{g}-\mathrm{a}$ back to C-tonic). ${ }^{4}$ Already Sibelius' first movement's development section features a climactic closing section in mm. 208-262 on d (with upper $b_{b} b^{3}, c^{1}$ and $g_{b}{ }^{1}$ )-B $b$ (with upper $a_{b}$ )-G (with upper $\mathrm{e}^{1}$ )/F\#-E-D. ${ }^{5}$ Here the intervening whole-tone steps $\mathrm{D}-\mathrm{C}-\mathrm{B} b-\mathrm{A} b-\mathrm{G} b-\mathrm{E}-\mathrm{D}$ are present in the upper violin harmony notes. Sibelius also carefully introduces this climactic progression $\mathrm{D}-\mathrm{C}-\mathrm{B}$, with several complementary, introductory whole-tone bass passages on D-E-F\# in mm. 1-55. This initial linear ascent is then continued via the pitches $\mathrm{d}^{1}-\mathrm{E}-\mathrm{F} \#-(\mathrm{G})-\mathrm{G} \#$ in $\mathrm{mm}$. 48-58 and C-D-E in mm.100-102. Moreover, the beginning of the development also highlights the bass $\mathrm{A} b$ (echoing its enharmonic cousin $\mathrm{G} \#$ from 57-58) in 142-143 and the related c-minor (compare the preceding 100-101!) in $152_{1}+156-160$ before once again settling down on D's central tritone of G\# in 164-172. The intervening mm. 170-208 likewise outline analogous whole-tone progressions on $\mathrm{g \#}$ (170)/a b (182 ${ }_{1}$, bassoon)-a\# (173)/b b (183 ${ }_{1}$, clarinet $)-c\left(181_{1}\right.$, viola; $184_{1}$, bassoon and $193_{2}$, violoncello)-d (194, timpani).

A similar structural whole-tone scaffold on $\mathrm{D}-\mathrm{C}-\mathrm{B}_{b}-\mathrm{A}_{b}-\mathrm{G}_{b} / \mathrm{F} \#-\mathrm{A} b-\mathrm{B}_{b}$ is then repeated in cyclical fashion in the third movement's Scherzo, mm. 94-145+146-161 (:Trio and varied reprise of Scherzo in 159f.). Moreover, the identical line of D-C-B $b$ recurs in the Finale's Coda, mm. 340-348: a passage initially sketched as an orchestral Intrada in HUL 1539/3, lines 3-4, where the pitch $\mathrm{C}$ is still tonally harmonized with a $\mathrm{V}^{7}$ chord on D. ${ }^{6}$ Moreover, the clear tonal close on D-major in this sketch is at sharp variance with the modal lines on $\mathrm{D}-\mathrm{C}-\mathrm{B}$ b of the final version.

Musical example 1: Sketched Intrada for Finale, mm. 340-348 from HUL 1539/3, lines $3-4$

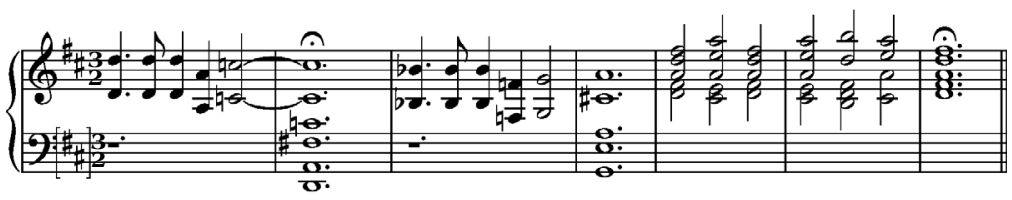

The major third interval is also important in a motivic sense in Sibelius' Second Symphony. The opening theme group in the first movement, $\mathrm{mm} .1-32$ is a case in point, since it

4 Nors S. Josephson, "Zirkelartige Progressionen in symphonischen Durchführungen der Klassik und Romantik,” Die Musik forschung 34 (1981): 292-300, especially 294-295.

5 Lionel Pike, Beethoven, Sibelius and the "Profound Logic" (London: Faber and Faber, 1978), 92, cited in Vignal, p. 325.

6 This D-major Intrada was also apparently originally intended as in introductory episode for the developmental transition in (Finale) 127f. over the Finale's main theme, d-e-f\#-c\#-d-e etc. See HUL 0150 [1], lines 1-2. 
outlines two third aggregates, $\mathrm{d}-\mathrm{fH}-\mathrm{a}$ and e-g. ${ }^{7}$ This transposition on the scalar degrees Iii was much used in the symphonic literature of the $19^{\text {th }}$ century; one is especially reminded of the opening of Beethoven's First Symphony (1800) and Brahms' Second Symphony (1877). Similar third configurations occur at the outset of the second (slow) movement ( $d-f$ and $e-g$ ) and the beginning of the Finale $\left(d^{2}-f \#^{2}\right.$ oscillating with $\left.c \#^{2}-e\right)$. The final glorious trumpet apotheosis at the close of the Finale's Coda, mm. 356-373 amalgamates these tertial cells into a stirring climax on $\mathrm{d}^{2}-\mathrm{e}^{2}-\mathrm{fH}^{2}-\mathrm{g}^{2}$ that ultimately reaches the high peak $\mathrm{a}^{2}$, or D's dominant. This passage has already been adumbrated at the end of the first movement's development, mm.257-259, and again highlighting the trumpets! ${ }^{8}$

Musical example 2: Trumpet climaxes in I (257-259) and IV (356-364)

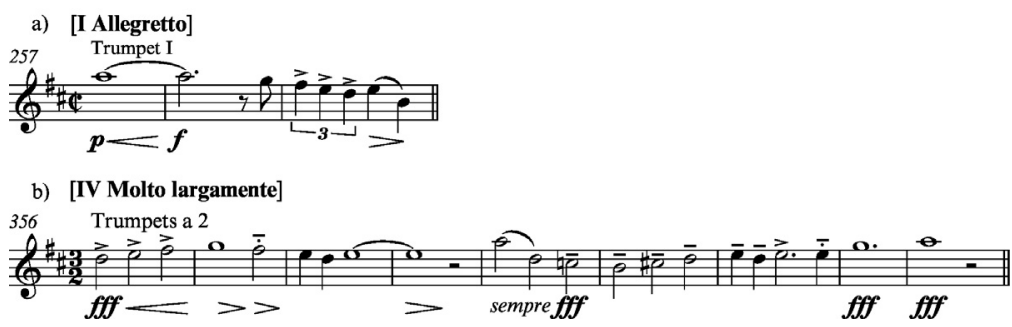

Sibelius provides for thematic contrast in his Second Symphony by means of a family of chromatically oscillating motives that are at times indebted to earlier German Romantic composers, notably Bruckner and Wagner. ${ }^{9}$ In particular, four brief thematic gestures from Bruckner's Third Symphony (composed in 1873 and revised in 1877 and 1890) and Wagner's Götterdämmerung (namely, Siegfried's Funeral March from Act III, completed in 1874) appear to have subliminally inspired Sibelius's opening bassoon theme of his second movement (mm.40-55), the Tutti outbursts ${ }^{10}$ in II, 80-97, the lyrically contrasting Christus subject (mm. 98-105) in the same slow movement plus the opening of the Scherzo:

7 On the concentrated tonal-motivic integration and melodic connections in the first movement's mm.1-262, see Ilkka Oramo's detailed analysis in his essay "Motiivi ja muoto Sibeliuksen toisessa Sinfoniassa," Musiikki 8 (1978): 1-27.

8 Haas, "Sibelius's Second Symphony," 91 also views these two passages as interrelated and believes that the end of I's development foreshadows the Finale's Coda-apotheosis (which Sibelius first improvised in June, 1899 at the home of Gallén-Kallela; see Vignal, Jean Sibelius, 278).

9 Murtomäki, Symphonic Unity, 34 believes that Sibelius' music literally overflows with Wagnerisms, such as the Tristan chord, although in his old age the Finnish master frequently denigrated the German composer.

10 Haas, "Sibelius's Second Symphony," 85 describes Sibelius' Tutti in this passage as featuring "Brucknerian registral shifts". In his book, Jean Sibelius: Progressive Techniques in the Symphonies and Tone-Poems (New York: Garland Publishing, 1989), 12 Tim Howell stresses that the concept of three medial keys is also likely a Bruckner influence. 
Musical example 3: Brucknerian and Wagnerian creative stimuli for Sibelius' Second Symphony

a) Bruckner, Third Symphony: II, 1-2

Adagio, bewegt, quasi Andante

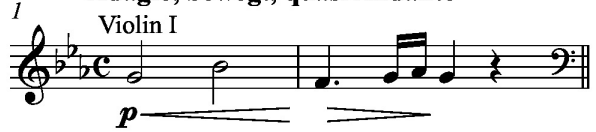

Sibelius, Second Symphony: II, 40-43

[Tempo Andante, ma rubato]

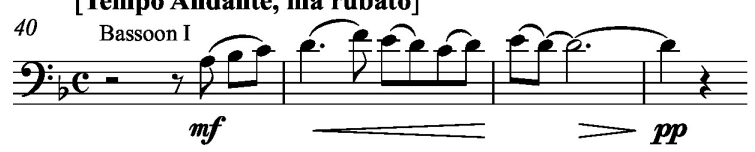

b) Bruckner, Third Symphony: I, 39-45 (: Reduction)

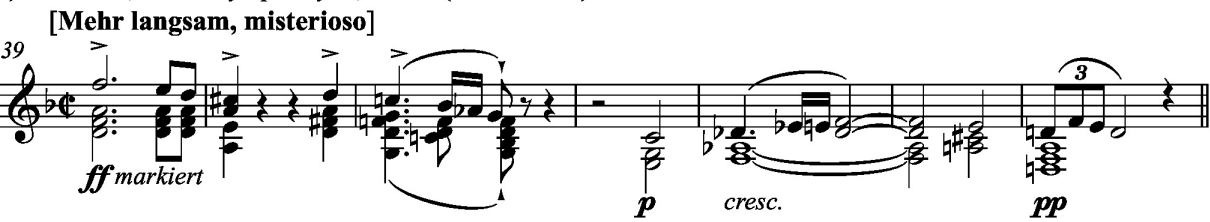

Sibelius, Second Symphony: II, agitated Tutti (Reduction) 80-82 ...

[Poco largamente]

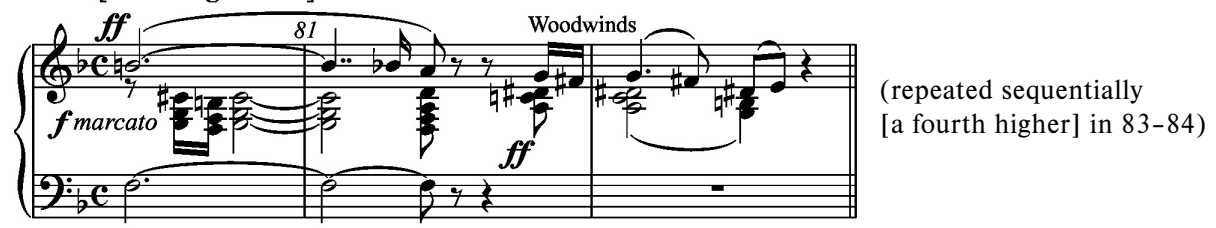

... 85-97

Molto largamente
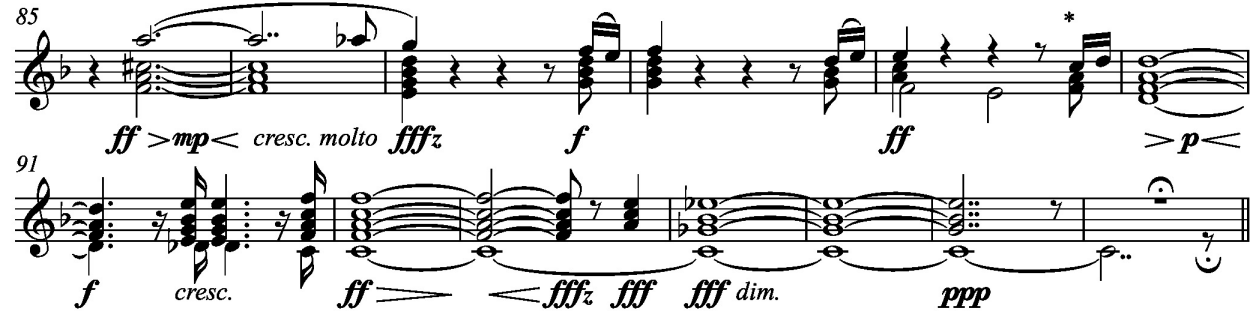

*) Cf. Bruckner's rising cadential figure on $\mathrm{c}^{1}-\mathrm{d} b^{1}-\mathrm{e} b^{1}-\mathrm{e}^{1}-\mathrm{f}^{1}$ in his $\mathrm{mm} .42-45$

Cf. also Sibelius' 1896-1899 sketch in HUL 0129 [2], lines 1-4:

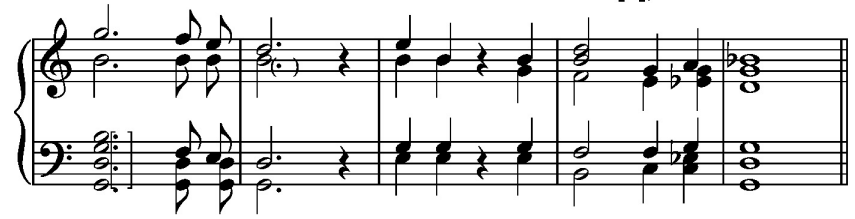


c) Wagner, Siegfried's Funeral March from Götterdämmerung: III, 987-988

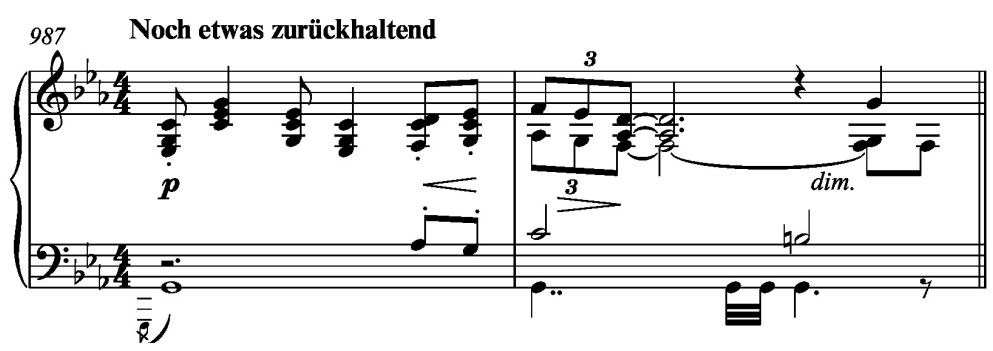

Sibelius, Final form of Christus theme from Second Symphony: II, 98-100

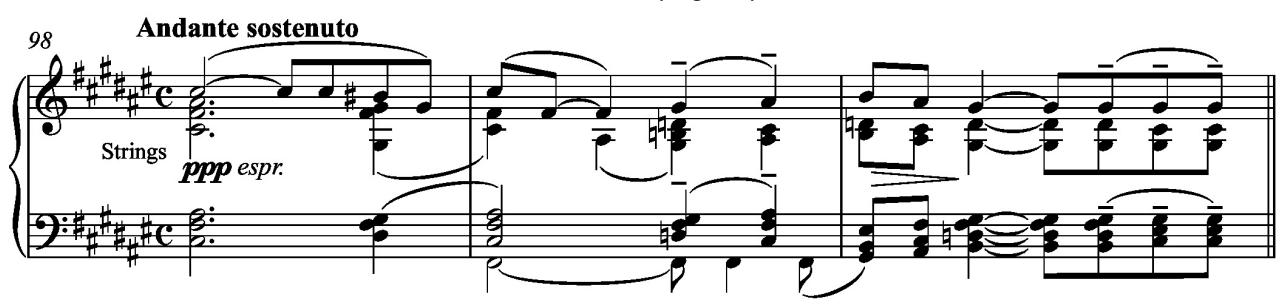

d) Bruckner, Third Symphony: III, 17-19

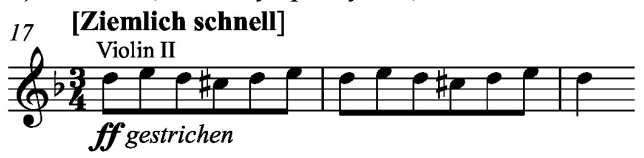

Sibelius, Second Symphony: III, 1-2

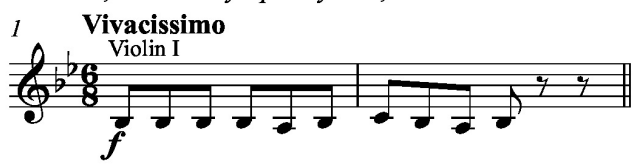

Cf. also Dvořák, Sixth Symphony: III, 5-8

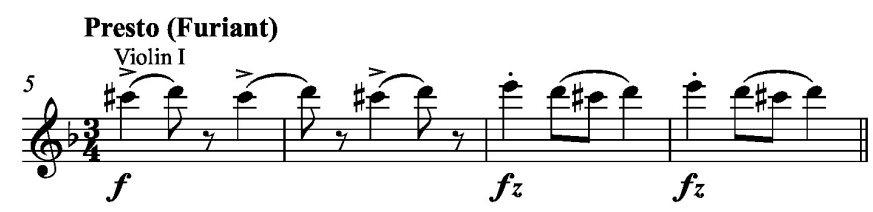

Significantly, the apparent Wagner and Bruckner quotations in the last three examples all begin with minor seconds (such as $\mathrm{d}^{1}-\mathrm{eb}^{1}$ in Götterdämmerung) followed by major seconds; the reverse is true in Example 3d, but Sibelius turns Bruckner's germ cell into the expected minor-major second sequence. We know that Sibelius had heard Bruckner's Third Symphony in Vienna in 1890 and was much impressed by the work and its creator, 
whom he considered to be the greatest living composer. ${ }^{11}$ A similar contemporary scherzo - also in d-minor like Bruckner's - is encountered in the third Furiant movement of Dvořák's Sixth Symphony (1880), where the main theme reads, $c \#^{3}-\mathrm{d}^{3}-\mathrm{c} \#^{3}-\mathrm{d}^{3}-\mathrm{c} \#^{3}-\mathrm{d}^{3}-\mathrm{e}^{3}-$ $d^{3}-c \#^{3}-d^{3}$. Here it should be mentioned that both compositions were conducted during this time-period by the Viennese conductor Hans Richter.

Sibelius must have been partial to these alternating minor/major seconds, because he also employs them as ornamental turns in the first three movements (for example, I, 85-102; II, 108 and III, 147f.). More importantly, they recur in cyclical fashion as the finale's elegiac second subject in mm.79-80f. and 273-274f. This haunting cantilena was apparently inspired by the suicide-death of his sister-in-law Elli Järnefeld on July 3, 1901. ${ }^{12}$

Musical example 4: Finale's elegiac second subject in 79-80f.

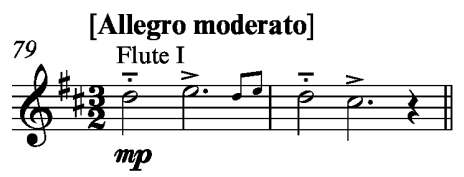

Moreover, these minor second intervals also affected the overall tonal organization of the second movement, whose d-minor Tutti outbursts in mm. 80-97 are transposed to d's unstable leading-tone $\mathrm{c} \#$ in 170-173. These chromatic vacillations may also reflect on what Sibelius himself termed the "spiritualized development" of the second movement, progressing from Don Juan's encounter with death to the above-mentioned redemption of the Christ theme. ${ }^{13}$ In this connection it is revealing to speculate on the philosophical meaning of Sibelius' draft in HUL 0146, which expands the Christus theme into ethereal, redemptive $\mathrm{D}$-major harmonies that may represent an original ending for the slow movement.

Musical example 5: Redemptive ending in $\mathrm{D}$-major (Sibelius writes "Des dur") for Sibelius' slow movement in Second Symphony sketch in HUL 0146 [1], line 9-12

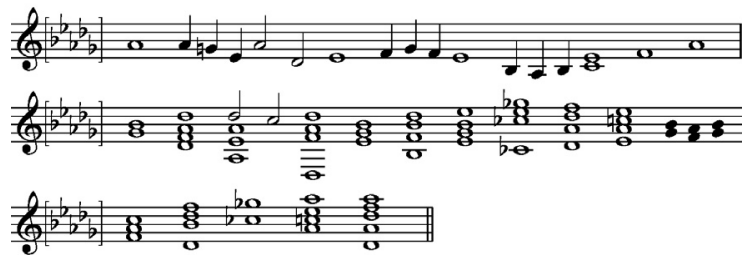

1 See Sibelius' letter to his future wife Aino of December 21, 1890, partly reproduced in Vignal, Jean Sibelius 127.

12 Vignal, Jean Sibelius, 332.

13 Haas, "Sibelius's Second Symphony," 88-90. 
Analogous $\mathrm{D} / \mathrm{Db}$ vacillations are encountered in the third movement (Scherzo) between mm.72-73 (D) and 80-81 (Db). ${ }^{14}$

Similarly, HUL 0152 [1], lines 5-9 sketch some evocative, ethereal Eb (or D: Neapolitan bII degree) tremolos for the Finale's Coda. Similar Eb shadings were originally planned in HUL 0150 [1-2] for the climactic transition leading up to the reprise in m.197f.

Musical example 6: Eb/D vacillations in sketch for the Finale's Coda in HUL 0152 [1], line 5-9

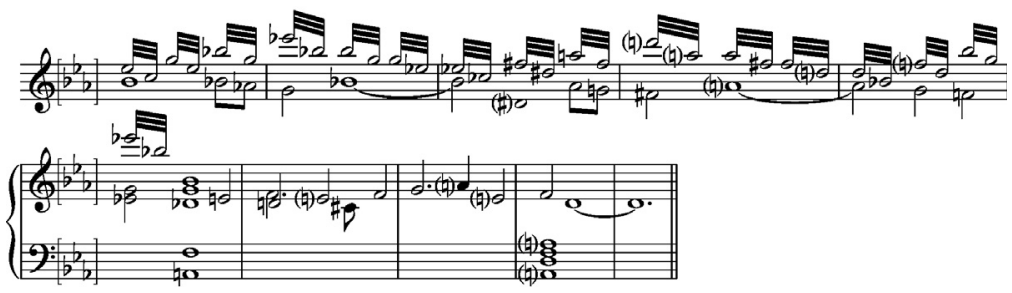

In conclusion, Sibelius' Second Symphony emerges as a transitional watershed work. While his employment of cyclical third intervals and redemptive endings (such as the original $\mathrm{D}_{b}$ close of II, or the $\mathrm{E} b$ Neapolitan shadings in IV's Coda) suggest a familiarity with Beethoven, Brahms and Wagner, his usage of repeated, static ostinatos and modal structures (including Lydian-style tritones, auch as D-G\#) point to later $20^{\text {th }}$-century developments. Moreover, Sibelius' consistent drawing on linear whole-tone matrices link these tritone and major third structures to the work's larger contrapuntal network. One is reminded of Vignal's perceptive comment to the effect that the Second Symphony at once fully amalgamates the German-Austrian symphonic tradition, but also looks far ahead into the future. ${ }^{15}$

14 These minor second relationships (D-C\#/D-D $b$ and $D-E_{b}$ ) distinctly recall the analogous minor second scaffolds (Eb/D, D-D b) in Borodin's First Symphony of 1867. The latter Russian symphony had been performed in Helsinki on October 15, 1896 (see Howell, Jean Sibelius: Progressive Techniques, 8). In addition, numerous scholars have commented on certain structural similarities between Borodin's First Symphony and Sibelius' First Symphony of 1899 (see summary in Vignal, Jean Sibelius, 270-271), even though Sibelius emphatically denied having known the Borodin work before composing his own First Symphony. More to the point is Howell's (Jean Sibelius: Progressive Techniques, 12) assertion that the synthesis climaxes in Sibelius' Second Symphony (such as: I's recapitulation or IV's Coda-epilogue) derive from Russian composers such as Tchaikovsky and Borodin.

15 Vignal, Jean Sibelius, 321. 


\title{
Sibelius at the Crossroads: Old Paths Leading to New Creative Departures in His Second Symphony (1901/02)
}

\begin{abstract}
Sibelius' Second Symphony derives its inspiration from several third intervals that were originally also used in Brahms' Second Symphony. These third cells are often linked via major second scalar progressions, resulting in recurring whole-tone scales, a concept already employed in Classical development sections. In addition, Sibelius' Second Symphony was also much influenced by Bruckner's Third Symphony, notably the latter's first three movements. Sibelius' sketches for the second and fourth movements also indicate that the composer toyed with the idea of transcendental codas for these sections, producing minor second harmonic relationships that may derive from Borodin's first two symphonies.
\end{abstract}

\section{Sibelius na rozcestí: tradiční cesty, jež vedou k novým tvưrčím východiskům, na př́kladu skladatelovy Symfonie č. 2 (1901/02)}

\begin{abstract}
Abstrakt
Sibeliova Druhá symfonie čerpá inspiraci z některých terciových intervalových struktur, které se původně objevily v Brahmsově Druhé symfonii. Tyto terciové buňky jsou propojeny prostřednictvím stupnicových postupů velkých sekund, jež ústí v celotónové stupnice koncept, který je znám již z evolučních sekcí klasicistní hudby. Sibeliova Druhá symfonie byla do značné míry rovněž ovlivněna Brucknerovou Třetí symfonií, zejména jejími prvními třemi větami. Sibeliovy skici druhé a čtvrté věty dále naznačují, že si zde autor zahrával s myšlenkou využití transcendentní kódy s výsledkem harmonických vztahů na bázi malých sekund, které mohou být odvozeny z Borodinových prvních dvou symfonií.
\end{abstract}

\section{Keywords}

Sibelius; Second Symphony; structural analysis; inspirations.

\section{Klíčová slova}

Sibelius; Druhá symfonie; strukturální analýza; inspirace. 